\title{
KÜRESEL KRİZ SONRASI ULUSLARARASI PARA BİRIMII OLARAK EURO VE GELECEĞİ
}

\author{
Yrd. Doç. Dr. Umut EVLIMMOĞLU* \\ Yrd. Doç. Dr. Yasemin BOZDAĞLIOĞLU**
}

\begin{abstract}
ÖZ
Avrupa Birliği uzun uğraşlar sonucunda ekonomik bütünleşmeşekillerinden biri olan ekonomik ve parasal birliği 1999 yılında gerçekleştirmiş ve bazı Avrupa Birliği üyeleri 2002 yılından itibaren kendi para birimleri yerine ortak para birimi olan Euro'yu kullanmaya başlamışlardır. Bugün itibariyle 18 ülkenin olușturduğu ortak para alanına "Euro Alanı" denmektedir. Euro'nun yürürlüğe girmesinden itibaren Euro'nun geleceğine ilişskin soru işaretleri hep var olmuştur. Bu süreçte Euro'nun uluslararası bir para birimi olup olamayacağı, dolartn hâkimiyetini kirtp kuramayacağı gündeme gelmiştir. Küresel krizin başlamasından ve özellikle bu krizin "Avrupa Borç Krizi” haline gelmesinden sonra, Euro'nun uluslararası para birimi niteliği ve geleceği daha fazla sorgulanır hale gelmiştir. Bu çalışmanın amacı; uluslararası para birimlerinin taşıması gereken nitelikleri ortaya koyarak, Euro'nun küresel kriz sonrasında uluslararası para birimi olma niteliğini sorgulamak, Euro 'nun geleceğine yönelik olarak olasılıkları ortaya koymaktır. Ortaya konulan olasılıklar arasında var olma olasılı̆̆ının diğer olasılıklara göre daha güçlü bir olasılık olduğu sonucuna ulaşılmıştır.

Anahtar Kelimeler: Euro, Euro Alanı, Uluslararası Para Birimi
\end{abstract}

Jel Sinıflandırmast: F15, F31, F33

\section{THE EURO AND ITS FUTURE AS AN INTERNATIONAL CURRENCY IN THE POST- CRISIS PERIOD}

\begin{abstract}
Today, the common monetary zone that consists of 18 countries is called the "Euro Zone." The countries included in this zone use the Euro as a common currency unit instead of their national currencies. There have always been question marks about the future of the Euro since the Euro was put into effect. In the process, whether the euro could become an international currency and whether it could end the dollar's supremacy have been brought to the agenda. After the global crisis started and
\end{abstract}

\footnotetext{
*Adnan Menderes Üniversitesi, Nazilli İktisadi ve İdari Bilimler Fakültesi, uevlimoglu@adu.edu.tr

*** Adnan Menderes Üniversitesi, Nazilli İktisadi ve İdari Bilimler Fakültesi
} 
especially after the crisis turned into the "European Debt Crisis" the eligibility of the Euro to become an international currency and its future started to be questioned even more. The purpose of this study is to examine whether the Euro has the qualities as an international currency unit and to present possibilities about the future of the Euro by explaining the characteristics that international currencies must have. It was observed that the Euro maintains the properties of being an international currency unit and it has a strong likelihood to continue to exist compared to other possibilities presented so far.

Key Words: Euro, Euro Zone, International Currency

Jel Classification:F15, F31, F33

\section{GİRIŞ̧}

Avrupa Birliği’nin 18 üyesinin oluşturduğu alan günümüzde Euro alanı olarak adlandırılmaktadır. İlk aşamada 12 üye kendi para birimlerini terk ederek, Euro'yu kendi ulusal paraları olarak kabul etmişlerdir. Euro, bugün çok büyük bir alanda dolaşımda bulunmaktadır. $\mathrm{Bu}$ alanda fiyatlandırmalar alış-verişler Euro ile yapılmaktadır. Ayrıca, Euro alanı ülkeleri dünyada önemli bir ağırlığa sahip ülkelerdir. Bu ülkeler, gerek dünya ticaretinde gerekse de dünya üretiminde önemli rol oynayan ülkelerdir. Bu ülkelerin birleşmesiyle oluşan Euro alanı da dünyada güçlü bir ekonomik potansiyele sahip olmuştur.

Günümüzde Euro, gerek ekonomik açıdan, gerek yüzölçümü açısından ve gerekse de nüfus açısından çok büyük bir bölgeyi kapsamaktadır. Euro'daki değişimler sadece bu alandaki ülkeleri değil, bu alanla ticarette bulunan diğer ülkeler için de son derece önem taşımaktadır. Bu bakımdan Euro giderek diğer ülkeler tarafından da yakından takip edilmektedir.

Euro'nun yürürlüğe girmesinden itibaren ekonomik çevrelerde Euro'nun geleceğine yönelik olarak belirsizlikler ve tartışmalar hep devam etmiştir. Küresel krizin başlaması, daha sonra Avrupa'ya sıçrayarak "Avrupa Borç Krizi” halini alması ve başta Yunanistan olmak üzere bazı Euro bölgesi ülkelerinin ekonomik anlamda zor duruma düşmesi Euro'nun ve Euro bölgesinin geleceğine yönelik olarak soru işaretlerini artırmıştır. Bu süreçte zor durumda olan ülkelerin para politikası araçlarını kullanamamalarından dolayı, krizden çıkışlarının daha uzun bir sürece yayılacağı gibi görüşler hakim olmuştur. Avrupa'daki krizin aşılması yönünde gerek Avrupa Merkez Bankası gerekse de birliğin önde gelen ülkeleri birçok adımlar atmışlardır. Euro'nun uluslararası para birimi niteliğini devam ettirmesi, Euro bölgesinin geleceğini yakından ilgilendirmektedir. Avrupa'daki krizin derinleşmesi ya da hafiflemesi, krize yönelik olarak atılan adımların sonuç vermesi ya da vermemesi ve ülkelerin alacakları kararlar Euro bölgesinin geleceği hakkında farklı olasılıkların ortaya çıkmasına sebep olmaktadir. 


\section{AVRUPA'DA EURO SÜRECI}

Avrupa'da bir Ekonomik ve Parasal Birlik oluşturma fikri geçmişten beri var olmuştur. Buna yönelik olarak, Toplulukta birçok adımlar atılmıştır. Bu yönde yapılan bazı denemeler ise, başarısızlıkla sonuçlanmıştır. Avrupa Para Sisteminin (APS) devreye girmesi ve başarılı bir şekilde uygulanması, Avrupa'da Ekonomik ve Parasal Birliğin gerçekleştirilmesine yönelik yeni bir oluşuma gidilmesi fikrini Topluluk ülkeleri arasında güçlendirmiştir. Topluluğun Ekonomik ve Parasal Birliğe geçmesini zorlayan en önemli faktörlerden biri de Tek Pazarın oluşmasıdır. Tek para biriminin tek pazarın tamamlayıcı bir unsuru olacağı görüşü; APS'nin daha da genişletilmesini zorunlu hale getirmiştir. Haziran 1988'de Hannover'de yapılan zirvede Topluluğun Ekonomik ve Parasal Birliğe (EPB) geçmesi fikri kabul görmüş ve bu yönde yapılacakların belirlenmesi için J. Delors başkanlığında bir komite kurulmasına karar verilmiştir.

\section{1. Delors Raporu}

Hannover Zirvesi’nde kararlaştırıldığı şekliyle J. Delors başkanlığında kurulan komite, EPB'yi gerçekleştirmeye yönelik çalışmalarını Nisan 1989'da tamamlamış ve Topluluğa sunmuştur. Delors Raporu, Haziran 1989'da Madrid Zirvesi'nde görüşülerek kabul edilmiştir. Rapor, EPB'ye geçiş için aşamalı bir süreç önermiştir. Raporda, parasal birliğin gerçekleştirilebilmesi için üç ön koşulun olduğu belirtilmiştir (Savaş, 1999:29):

1. Bütün ulusal paraların sınırsız ve değiştirilemez biçimde konvertibl olması,

2. Sermaye akımlarının tümüyle liberalleştirilmesi ve bankacıllk sektörü ile diğer finansal piyasaların tam bütünleşmesi,

3. Geriye dönülmez biçimde sabitleştirilmiş döviz kurlarının belirlenmesi ve dolayısıyla kur değişmelerinin ortadan kaldırılmasıdır.

Raporda; üç aşamadan sadece birinci aşamanın başlangıç tarihi belirtilmiş ve 1 Temmuz 1990'da başlaması kararlaştırılmıştır. Diğer aşamaların başlangıç tarihlerinin belirlenmesinde üye ülkeler arasındaki yakınlaşmaların ne derecede olacağının ve 1. aşamada sayılan unsurların hangi tarihte gerçekleştirilebileceğinin belirleyici olacağı söylenmiştir.

Raporda, 1'inci aşamada yapılması gerekenler şu şekilde belirtilmiştir (Arısan, 1997:19):

\section{Ekonomik Alanda:}

- Fiziki, teknik ve mali engellerin tümüyle kaldırılması ve $\mathrm{AB}$ Rekabet Politikasının güçlendirilmesi,

- Bölgesel kalkınmanın ve ekonomik dengesizliklerin düzeltilmesi sürecinin hızlandırılması,

- Fiyat istikrarının sağlanması, 
- Kamu maliyesinin sağlamlaştırılmasıdır.

\section{Parasal Alanda:}

- Sermaye hareketlerinin serbest dolaşımına ilişkin tüm kısıtlamaların kaldırılması,

- Tüm üye devletlerin APS’nin Döviz Kuru Mekanizması'na katılması,

- ECU’nün özel kullanımı önündeki bütün engellerin kaldırılması,

- Merkez Bankalarının bağımsız hale getirilmesidir.

İkinci aşamada; Avrupa Para Enstitüsü’nün kurulması ve EPB'nin tamamlanması ile birlikte, bu kurumun üçüncü aşamada Avrupa Merkez Bankasına dönüştürülmesi ve AMB'nin AB'nin para politikasını bağımsız bir şekilde yönlendirmesi öngörülmüştür. İkinci aşamanın, üye devletlerin ilk aşama için öngördükleri ekonomik politikaları yaklaştırma çabalarının sürdürüleceği ve arttırılacağı bir geçiş dönemi olması planlanmıştır. Bu aşamada, mevcut kurumların gözden geçirilmesi ve yenilerinin kurulması da dahil olmak üzere EPB'nin kurumsal altyapısının oluşturulması öngörülmüştür (Arısan, 1997:20-21). Ayrıca, ikinci aşamada Avrupa Merkez Bankaları Sistemi'nin kurulması ve ulusal paraların dalgalanma marjlarının daraltılması önerilmiştir.

Üçüncü aşamada ise Avrupa Merkez Bankaları Sistemi, para politikasını yönlendirmenin tüm sorumluluğunu üstlenmekte ve üye ülkeler arasındaki döviz kurlarını değiştirilemez biçimde sabitleştirmektedir. Ayrıca, makroekonomi ve bütçe politikalarının koordinasyonu ile ilgili kararların bağlayıcı olması, Topluluğa ulusal bütçelere müdahale yetkisinin verilmesi, rezervlerin AMBS'de toplanması ve yürütülmesi ile ulusal paraların yerine tek bir para birimine geçilmesi istenmiştir (Kar, 2003:199).

\section{2. Maastricht Antlaşması (Avrupa Birliği Antlaşmașı)}

7 Şubat tarihinde toplanan Avrupa Topluluğu Devlet ve Hükümet Başkanları Maastricht Antlaşması'nı (Avrupa Birliği Antlaşmasını) imzalamıştır. Bu antlaşmanın imzalanması, Avrupa'da hem ekonomik ve parasal birliğin gerçekleştirilmesi yolunda hem de politik birliğin gerçekleştirilmesi yolunda atılmış en önemli adımlardan biridir. Bu antlaşma, diğer antlaşmalardan farklı olarak, önemli ve geniş kapsamlı değişiklikler getirmiştir. Topluluğun ilerlemesine de önemli katkı sağlamıştır.

Antlaşma, gelecekteki Avrupa'nın inşası için gerekli zemini oluşturma; birliği oluşturan toplumların kültür ve geçmişini göz ardı etmeden dayanışmayı güçlendirme, demokrasiyi, temel hak ve hürriyetleri pekiştirme gibi tarihi ve siyasi hedefler ortaya koymaktadır (DTM, 1999:43-44).

Birliğin hedeflediği dengeli ve sürdürülebilir ekonomik ve sosyal gelişme, ekonomik ve sosyal anlamda bütünleşme için, bir EPB'nin oluşturulması ve birlik çapında tek bir para biriminin geçerli olmasının gerekliliği kavranmıştır. Maastricht Antlaşması birliğe yeni bir dinamizm kazandırmış ve günümüz Avrupa'sının temellerini atmıştır. 
Maastricht Antlaşması'nda üye ülke ekonomileri arasındaki farklılıkların giderilebilmesi için bazı makro büyüklükler açısından yakınlaşma ölçütleri belirlenmiştir. Aynı zamanda, bu ölçütler ülkeler için EPB'nin son aşamasına geçiş ölçütleridir. Maastricht Kriterleri ya da konverjans (yakınlaşma) kriterleri diye de anılan bu kriterler; enflasyon oranı kriteri, faiz oranı kriteri, bütçe açığı kriteri, borç kriteri, döviz kuru kriterinden oluşmaktadır (DTM, 1999:151).

\section{3. Ekonomik ve Parasal Birliğin Aşamaları}

Maastricht Antlaşması'nda Ekonomik ve Parasal Birliğin gerçekleştirilmesi hedefi kabul edildikten sonra, bu hedefe ulaşma üç aşamada gerçekleşmiştir. Birinci aşamadan üçüncü aşamaya kadar ülkeler, Ekonomik ve Parasal Birliğin gerçekleştirilmesi için birçok adımlar atmışlardır. Tablo1'de, ekonomik ve parasal birlik açısından üç aşamada yapılanlar ayrı ayrı şekilde gösterilmiştir.

Tablo1. Ekonomik ve Parasal Birlik Aşamalarında Yapılanlar

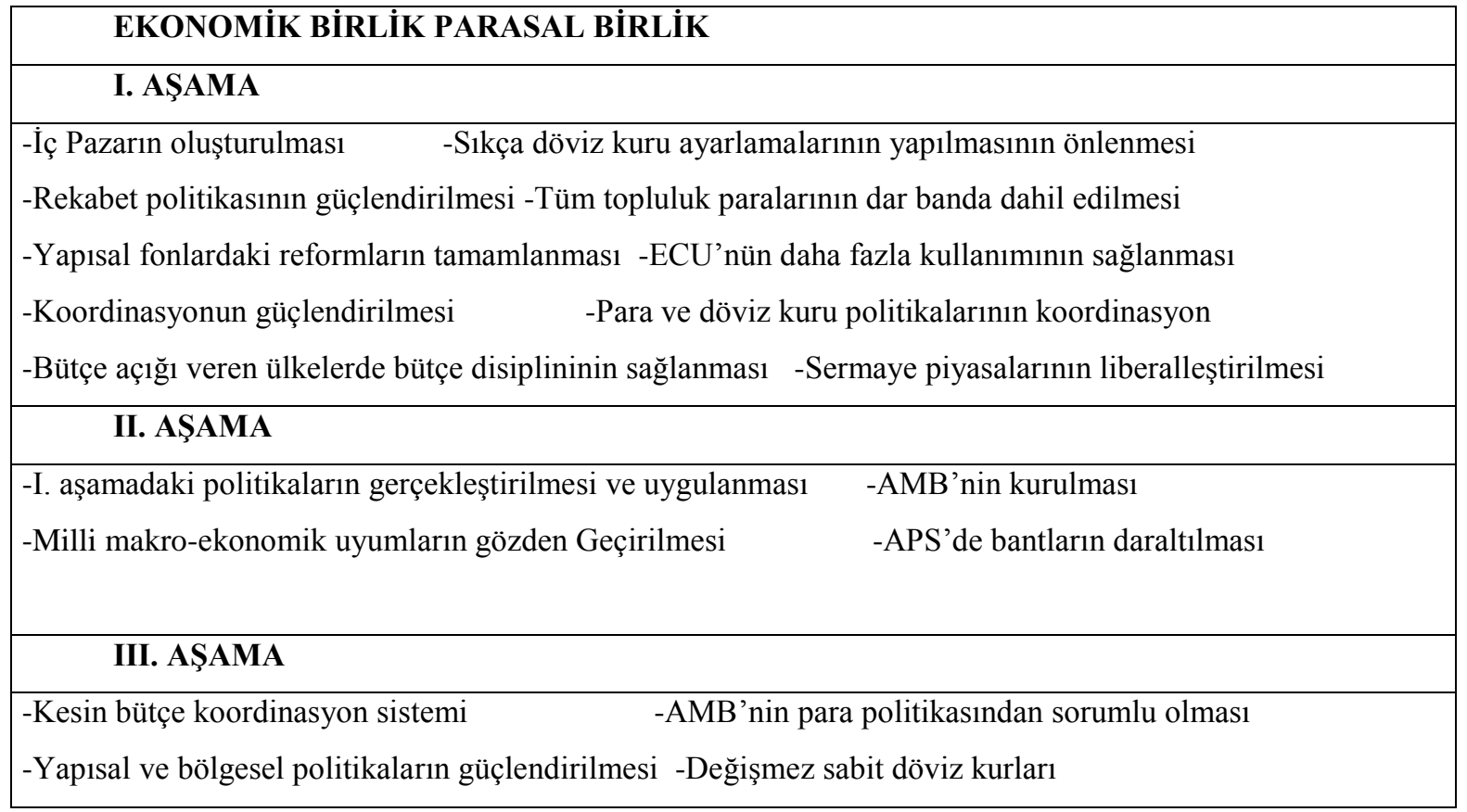

\section{Kaynak: Karluk, Rıdvan 2002 “Uluslararası Ekonomi” s:596}

Birinci aşama; 1 Temmuz 1990 tarihinde başlamış 31 Aralık 1993 tarihinde sona ermiştir. Maastricht Antlaşması öncesinde geçen bu süreçte özellikle, tek pazarın tamamlanması yönünde çalışmalar yapılmıştır. Bunun için de serbest dolaşımın önündeki bütün engelleri kaldırmaya odaklanılmış ve özellikle de, sermaye hareketleri serbestleşmesi üzerinde durulmuştur. Bunun dışında ekonomik ve parasal birliğin her aşamasında önemli olan; üye ülkeler arasındaki ekonomi ve maliye politikalarının birbirine yaklaştırılması konusuna da önem verilmiştir.

1994 başında başlayan ikinci aşamada, para birliğine geçmek için yapılan çalışmalar hızlanmıştır. Bu aşamadaki en önemli adım Avrupa Para Enstitüsü'nün (APE) kurulmasıdır. APE, para politikalarının koordinasyonunu güçlendirmek, ECU'nün kullanılmasını teşvik etmek ve 3'üncü 
aşamada Avrupa Merkez Bankası'nın kurulması için gerekli zemini hazırlamak üzere kurulmuştur (Coşkun, 2001:85).

İkinci aşamadaki diğer önemli gelişmeler ise (Karluk ve Tonus, 1998:277):

- Kamu sektörünün finansmanını yasaklayan yasal düzenlemeler,

- Finans sektöründe kamu sektörü kuruluşlarına ayrıcalıklı yer verilmemesini sağlayacak düzenlemeler,

- Üye ülkelerin kamu sektörü sorumluluklarının birlik veya bir başka üye ülke tarafından üstlenilmesini engelleyen düzenlemeler,

- Üye ülkelerin aşırı bütçe açıklarından korunması için üye ülkelerin bütçe performanslarının izlenerek, gerektiğinde düzenleme yoluna gidilmesi,

- Üye ülkelerin merkez bankalarına yasal olarak bağımsızlık statüsünü kazandırmaktır.

$\mathrm{Bu}$ aşamada, Maastricht Yakınlaşma Kriterlerini diğer bir ifadeyle Euro alanında katılım ölçütlerinin ya da EPB'nin son aşamasına geçiş ölçütlerini hangi ülkelerin sağlayıp sağlamadıkları incelenmiştir (Kar, 2003:204). Ülkelerin Maastricht kriterleri karşısındaki bu aşamadaki durumu Tablo 2'de de görülmektedir. Öte yandan Danimarka, İsveç ve İngiltere Maastricht Kriterlerini büyük ölçüde yerine getirmekle birlikte, İngiltere ve Danimarka Maastricht Antlaşması'nın ekinde yer alan 11 ve 12 sayılı protokollerle tanınan "opt-out" (seçim) hakkını kullanarak, İsveç döviz kuru mekanizmasına katılmayarak zımnen, bir süre daha beklemeyi tercih ettiklerini ve 1 Ocak 1999 tarihinde resmen başlayan tek para sisteminin bu aşamada dışında kalacaklarını bildirmişlerdir. Yunanistan ise enflasyon, aşırı bütçe açığı, uzun vadeli faiz oranları ve döviz kuru kriterlerinin hiçbirini sağlayamadığından ilk etapta sistemin dışında kalmıştır. 1999 yılında EPB’nin üçüncü aşamasına 11 üye ülke ile geçilmiştir (Üstünkaya, 2001:32).Daha sonra, Yunanistan Maastricht Kriterlerini sağlamış ve 1 Ocak 2001 de Euro alanına dahil olmuştur.

Tablo2. Üye Ülkelerin EPB'nin Üçüncü Aşamasına Geçerken Maastricht Kriterlerine Uyumu

\begin{tabular}{|l|c|c|c|c|c|}
\hline & $\begin{array}{c}\text { Enflasyon } \\
\text { (a) } \\
\text { Ocak 1998 }\end{array}$ & $\begin{array}{c}\text { Bütçe Açı̆̆ } \\
\text { GSMH'nin } \\
\text { \% si (c) }\end{array}$ & $\begin{array}{c}\text { Borç } \\
\text { GSMH'nin } \\
\text { \%si (c) }\end{array}$ & $\begin{array}{c}\text { Uzun vadeli faiz } \\
\text { oranları (b) } \\
\text { Ocak 1998 }\end{array}$ & $\begin{array}{c}\text { Döviz Kurları } \\
\text { DKM'ye Katılım } \\
\text { Mart 1998 }\end{array}$ \\
\hline Referans Değer & $\mathbf{2 . 7}$ & $\mathbf{3 . 0}$ & $\mathbf{6 0 . 0}$ & $\mathbf{7 . 8}$ & Evet \\
\hline Belçika & 1.4 & 1.7 & 118.0 & 5.7 & Evet \\
\hline Almanya & 1.4 & 2.5 & 61.2 & 5.6 & Evet \\
\hline Yunanistan & 5.2 & 2.2 & 107.7 & $9.8(\mathbf{c})$ & Evet \\
\hline İspanya & 1.8 & 2.2 & 67.4 & 5.3 & Evet \\
\hline Fransa & 1.2 & 2.9 & 58.1 & 6.2 & Evet \\
\hline İrlanda & 1.2 & $-1.1($ fazla) & 59.5 & 6.7 & Evet \\
\hline İtalya & 1.8 & 2.5 & 118.1 & & 5.5 \\
\hline
\end{tabular}




\begin{tabular}{|l|c|c|c|c|c|}
\hline & $\begin{array}{c}\text { Enflasyon } \\
\text { (a) } \\
\text { Ocak 1998 }\end{array}$ & $\begin{array}{c}\text { Bütçe Açı̆̆ } \\
\text { GSMH'nin } \\
\text { \%si (c) }\end{array}$ & $\begin{array}{c}\text { Borç } \\
\text { GSMH'nin } \\
\text { \% si (c) }\end{array}$ & $\begin{array}{c}\text { Uzun vadeli faiz } \\
\text { oranları (b) } \\
\text { Ocak 1998 }\end{array}$ & $\begin{array}{c}\text { Döviz Kurları } \\
\text { DKM'ye Katılım } \\
\text { Mart 1998 }\end{array}$ \\
\hline Lüksemburg & 1.4 & -1.0 (fazla) & 7.1 & 5.6 & Evet \\
\hline Hollanda & 1.8 & 1.6 & 70.0 & 5.5 & Evet \\
\hline Avusturya & 1.1 & 2.3 & 64.7 & 5.6 & Evet \\
\hline Portekiz & 1.8 & 2.2 & 60.0 & 6.2 & Evet \\
\hline Finlandiya & 1.3 & 0.3 & 53.6 & 5.9 & Hayır \\
\hline İsveç & 1.9 & 0.5 & 74.1 & 6.5 & Hayır \\
\hline İngiltere & 1.8 & -0.6 (fazla) & 52.3 & 6.0 & Evet \\
\hline Danimarka & 1.9 & -1.1 (fazla) & 59.5 & 6.2 & \\
\hline
\end{tabular}

(a) Ortalama \% değişim

(b) Ortalama vade son 10 yil son 12 ayı ortalamas1

(c) GSYİH'nın \%'desi

(d) Enflasyon oranı ve faiz oranı için olan veriler Ocak 1998 sonuna kadarki 12 aylık periyod, bütçe açı̆̆ı ve borç için olan veriler ise 1998 Komisyon projeksiyonundan çıkan tahminler

Kaynak: Convergence Report 1998 s:25

Maastricht Kriterlerinin değerlendirmesini yapan AB Komisyonu ve APE hazırladıkları Uyum raporlarında, Belçika, Fransa, Avusturya, Portekiz ve İtalya'nın kamu açıkları alanında eksikleri olduğunu tespit etmiş, ancak iyileşme kaydettiklerini de göz önüne alarak bu ülkelerin EPB'nin üçüncü aşamasına geçişi için Konseye öneride bulunmuştur. Avrupa krizinde gelinen noktada görülüyor ki; bu iyileşme ilerleyen yıllarda tersine dönmüş ve özellikle Portekiz ve İtalya ve Yunanistan yüksek kamu borçları sebebiyle bir borç krizi içerisine sürüklenmiştir.

Maastricht Anlaşması'nda öngörüldüğü üzere Parasal Birliğin son aşamasına 1 Ocak 1999'da geçilmiştir. Bu aşamada, 1 ECU 1 Euro'ya eşitlenmiş ve ulusal paraların Euro’ya dönüşüm oranları geri dönülemez biçimde sabitlenmiştir. $\mathrm{Bu}$ aşamada, parasal birliğinin başarılı bir şekilde gerçekleştirilmesinde ve yürütülmesinde son derece önemli bir rol oynayan Avrupa Birliği Merkez Bankası kurulmuştur. Bu kurum, daha önceden planlandığı üzere APE’nin görevlerini devralmıştır. Ayrıca, üye devletlerde geçerli olacak para politikasını tek elden düzenlemeye başlamıştır.

Bütün bunların sonucunda, katılımcı ülkeler Euro'ya geçilmesine karar vermişler ve 1 Ocak 2002'den itibaren Euro banknot ve madeni paralar dolaşıma girmiş, ulusal paralar ise bir süre daha dolaşımda kalmış ve 1 Temmuz 2002 tarihinde ulusal paralar tedavülden kaldırılarak Euro, birliğin tek parası haline gelmiştir. Böylece 12 ülkeli bir Euro alanı oluşmuştur. İlerleyen tarihlerde ise bu alana yeni ülkeler eklenmiştir. Slovenya 2007, Kıbrıs Rum kesimi ve Malta 2008, Slovakya2009, Estonya 2011 ve Letonya 2014 y1lında bu alana dahil olmuşlardır. Bu ülkelerin de dahil olması ile beraber Euro alanı 18 ülkenin oluşturduğu bir alan haline gelmiştir.Bunun yanında Monako, San Marino ve Vatikan devletleri AB üyesi olmadıkları halde Euro'yu kendi resmi paraları olarak kullanma anlaşması imzalamışlardır. Ayrıca, Andorra, Kosova ve Karadağ da fiilen Euro’yu kendi para birimleri olarak kullanmaktadırlar. 
Euro alanının dünya ekonomisindeki yeri ve ekonomik potansiyelini ortaya koyabilmek açısından Tablo 3'e bakmak yararlı olacaktır. Tablo 3'de; Euro alanı, AB, ABD ve Japonya'nın bazı makroekonomik göstergeleri karşılaştırmalı olarak gösterilmektedir.

Tablo 3. Makro Göstergeler İtibarıyla Euro Alanı, ABD ve Japonya ve Karşılaştırılmasıı

\begin{tabular}{|c|c|c|c|c|c|}
\hline & Birim & Euro Alanı & AB & ABD & Japonya \\
\hline Nüfus & Milyon & 333.3 & 508.5 & 314.3 & 127.7 \\
\hline $\begin{array}{l}\text { İşgücüne } \quad \text { Katılma } \\
\text { Oranı }\end{array}$ & $\%$ & 72 & 71.7 & 73.3 & 73.8 \\
\hline GSYİH & Trilyon Euro & 9.5 & 13.5 & 12.3 & 3.5 \\
\hline İşgücü Verimliliği & Euro Alanı $=100$ & 100 & 91.9 & 133.4 & 88.4 \\
\hline \multicolumn{6}{|l|}{$\begin{array}{l}\text { Sektörlerin } \\
\text { İçindeki Payı }\end{array}$} \\
\hline $\begin{array}{l}\text { Tarım, Orman, } \\
\text { Balıkçılık }\end{array}$ & $\%$ & 1.8 & 1.8 & 1.2 & 1.2 \\
\hline Sanayi & $\%$ & 25.2 & 25 & 20 & 26.8 \\
\hline Hizmetler & $\%$ & 73.1 & 73.2 & 78.8 & 72.1 \\
\hline İşsizlik Oranları & $\%$ & 12.1 & 10.9 & 7.4 & 3.9 \\
\hline \multicolumn{6}{|l|}{ Genel Bütçe } \\
\hline Fazla(+)Açık (-) & GSYİH'nin \%'si olarak & -3.7 & -4.0 & -8.7 & -8.9 \\
\hline Ödenmemiş Brüt Borç & GSYİH'nin \%’ si olarak & 90.7 & 85.4 & 90 & 204.4 \\
\hline Harcama & GSYİH'nin \%' si olarak & 50 & 49.4 & 36.1 & 40.5 \\
\hline $\begin{array}{l}\text { Mal ve Hizmet } \\
\text { İhracatı }\end{array}$ & GSYİH'nin \%’ si olarak & 26.8 & 18.3 & 14.1 & 15.4 \\
\hline Mal ve Hizmet İthalatı & GSYİH'nin \%’ si olarak & 24.8 & 17.5 & 17.5 & 17.1 \\
\hline Cari İşlemler Dengesi & GSYİH'nin \%’ si olarak & 1.2 & 0.3 & -2.8 & 1 \\
\hline Brüt Tasarruflar & GSYİH'nin \%’ si olarak & 20.2 & 18.9 & 12.9 & 24.5 \\
\hline Krediler & Trilyon Euro & 16.4 & 22.3 & 12.2 & 10.4 \\
\hline BorsaKapitalizasyonu & Trilyon Euro & 4.5 & 7.5 & 16.0 & 2.7 \\
\hline
\end{tabular}

Kaynak: ECB Statistics Pocket Book, July 2013, s:7

Euro bölgesindeyaşayan 333 milyon kişi ulusal para birimi olarak Euro’yu kullanmakta ve Euro oldukça büyük bir alanda dolaşımda bulunmaktadır. Bu alanla bağlantılı diğer alanlarda da Euro dolaylı olarak kullanılmaktadır. Euro alanının GSYİH's1 9.5 trilyon Euro'dur. Dünya ihracatındaki pay ise, \% 32.2 olarak gerçekleşmiştir. Görüldüğü üzere Euro bölgesi dünyada ekonomik anlamda önemli bir yere sahiptir.

\section{KÜRESEL KRIZ SONRASINDA ULUSLARARASI PARA BİRIMİ NITTELİĞi AÇISINDAN EURO}

Euro'ya geçerken, Euro'nun dünya finans sisteminde nasıl bir yere sahip olacağı konusunda çekinceler vardı. Bazı iktisatçılar, Euro'nun, Doların alternatifi olamayacağını ve daha sınırlı bazda 
kalarak, AB içindeki ticarette etkili olacağını savunmaktaydılar. Bazıları ise Euro'nun, hem Dolar karşısında hem de uluslararası sistemde önemli bir yere sahip olacağı görüşündeydiler. Bu görüşlerden hangisinin ağırlık kazanacağı Euro alanında gösterilecek performansa dayalı olduğu kadar, diğer ülkelerin de tutumlarına bağlıydı. Euro'nun dolaşıma çıtığından itibaren gerek dünya finans sisteminde gerekse de uluslararası alanda beklenenin üzerinde bir etkiye sahip olduğu söylenebilir.

Euro alanı araştırmalarının yayınlandığı Eurobarometer'in 2003 yılında Euro alanı ülkelerde yapılan araştırmaya göre, Euro'ya geçişin yanında olanların yüzdesi \%89'lara kadar ulaşmaktadır (Eurobarometer, 2003:64). Bu oranın ilk aşamada bu kadar yüksek olması, üye ülkelerin Euro’yu kabullenmesinin bir göstergesidir. Güçlü bir para birimi olmanın ilk koşulu da, o paranın dolaşımda bulunduğu alanda kabul görmesi ve benimsenmesidir.

O halde, bir paranın uluslararası para birimi niteliği kazanması için ne gibi şartları yerine getirmesi gerektiği sorusu akla gelmektedir. Uluslararası paraların yerine getirmesi gereken fonksiyonlar literatürde şu şekilde belirtilmektedir:

Tablo 4. Uluslararası Paraların Fonksiyonları

\begin{tabular}{|l|l|l|}
\hline \multirow{1}{*}{$\begin{array}{c}\text { Paranın } \\
\text { Fonksiyonu }\end{array}$} & \multicolumn{2}{|c|}{$\begin{array}{c}\text { Uluslararası Paranın Kendi Ülkesi Dışında Yerleşik Olanlar } \\
\text { Tarafından Kullanımı }\end{array}$} \\
\cline { 2 - 3 } & Özel Sektör & Kamu Sektörü \\
\hline Tasarruf Aracı & Yatırım ve finansman parası Olması & Rezerv Para Olması \\
\hline Değişim Aracı & Ödeme Aracı Olması & \multirow{2}{*}{ Mübadele Parası Olması } \\
\cline { 2 - 2 } & Mal ve hizmet değişimi & \\
\cline { 2 - 3 } & Para değişimi & Kur Belirleme Standardı Olması \\
\hline \multirow{2}{*}{ Değer Ölçüsü } & Fiyatlandırma / Kotasyon & \\
\hline
\end{tabular}

Kaynak: ECB Montly Bulletin August 1999 s:32

Bir paranın uluslararası rezervlerde yer alması o paranın uluslararası niteliğini tanımlamada en önemli faktörlerden biridir. Diğer önemli faktörler ise o paranın özel sektör tarafindan yatırımlarda, finansmanda ve ödemelerde bir araç olarak kullanılmasıdır (Stark, 2000:2).

2007 y1lında başlayan küresel kriz, birçok ekonomik olayı derinden etkilemiştir. Krizin başlarında bir güven bunalımı oluşmuş, Lehman Brothers'ın batmasıyla bu güven bunalımı zirve noktaya tırmanmıştır. Amerikan dolarına olan güven azalmıştır. Daha sonra kriz Avrupa'ya sıçramış ve Avrupa Borç Krizi adını alarak buradaki ülkelerde kendini fazlasıyla hissettirmeye başlamıştır. Bu durum özellikle Avrupa Birliği'nin, Euro Alanının ve Euro'nun geleceğinin sorgulanmasına yol açmıştır. Küresel krizin etkilerinin yavaş yavaş azalmaya başladığı, ancak Avrupa'nın borç sorunlarının halen daha devam ettiği bu aşamada Euro'nun uluslararası para birimi niteliklerini taşıyıp taşımadığı ortaya koymak Euro'nun geleceği hakkında çıkarsamalarda bulunmak açısından önemli olacaktır. 
Buradan hareketle izleyen bölümlerde Euro'nun, Tablo 4'de verilen fonksiyonları ne ölçüde yerine getirebildiği tek tek ele alınmıştır. Euro'nun uluslararası para birimi niteliği de bu fonksiyonları yerine getirip getiremediği ile bağlantılıdır.

\section{1. Yatırım ve Finansman Parası Olarak Euro}

Para, gerçek ve tüzel kişilerin birikimlerini değerlendirebilmelerine imkân tanıyorsa, yatırım ve finansman parası olarak nitelendirilmektedir. Yatırım parasının en temel fonksiyonu "değer saklama" özelliğiyle ortaya çıkmaktadır. Bir paranın yatırım parası olarak değerlendirilmesindeki en önemli nokta, söz konusu paranın gelecekte de değerini koruyacağına ilişkin güvendir. Bu güven de paranın istikrarıyla oluşacaktır. Böylece yatırımcılar portföylerini söz konusu para birimi üzerinden değerlendireceklerdir (Olcay, 2006:138). Euro ile birlikte, Euro alanı içinde farklı paralardan kaynaklanan piyasaların bölünmüşlüğü ortadan kalkmış ve piyasada derinlik sağlanmıştır. Likiditesi artan piyasada bireysel ve uluslararası yatırımcılar daha geniş yatırım imkânlarına sahip olmuşlardır. Euro alanında fiyat istikrarının sağlanmasıyla beraber, yatırımcılar portföylerinde Euro cinsinden yatırım araçlarını bulundurmaya başlamışlardır (Birinci, 2001:75).

Tablo 5'de para birimlerine göre uluslararası mevduatların dağılımı gösterilmektedir. Yıllar itibariyle bakıldığında Euro cinsinden mevduatlarda sürekli bir artış olduğu görülmektedir. Krizin başladığı yıl olan 2007 yılından sonra küçük bir düşüş olsa bile, 2012 yılı itibariyle yeniden kriz öncesi seviyeye yaklaşılmıştır. Bu durum her şeye rağmen (Küresel kriz, AB krizi) kişilerin ya da şirketlerin mevduatlarını Euro olarak tutmaya devam ettiklerinin ve Euro'ya olan güvenin devam ettiğinin bir göstergesidir.

Tablo 5. Para birimlerine Göre Uluslararası Mevduatların Dağılımı

\begin{tabular}{|l|c|c|c|c|c|c|c|c|}
\hline & \multicolumn{4}{|c|}{ Miktar (Milyar \$) } & \multicolumn{4}{c|}{ Toplamın \%'si Olarak } \\
\hline Yıllar & Euro & Dolar & Yen & Diğer & Euro & Dolar & Yen & Diğer \\
\hline $\mathbf{2 0 0 0}$ & 391 & 1.303 & 85 & 323 & 18.6 & 62 & 4.1 & 15.3 \\
\hline $\mathbf{2 0 0 1}$ & 465 & 1.435 & 84 & 435 & 19.2 & 59.3 & 3.5 & 18 \\
\hline $\mathbf{2 0 0 2}$ & 598 & 1.542 & 93 & 555 & 21.5 & 55.3 & 3.3 & 19.9 \\
\hline $\mathbf{2 0 0 3}$ & 819 & 1.899 & 84 & 670 & 23.6 & 54.7 & 2.4 & 19.3 \\
\hline $\mathbf{2 0 0 4}$ & 992 & 2.201 & 112 & 770 & 24.3 & 54 & 2.8 & 18.9 \\
\hline $\mathbf{2 0 0 5}$ & 921 & 2.362 & 116 & 844 & 21.7 & 55.7 & 2.7 & 19.9 \\
\hline $\mathbf{2 0 0 6}$ & 1099 & 3.063 & 135 & 1.086 & 20.4 & 56.9 & 2.5 & 20.2 \\
\hline $\mathbf{2 0 0 7}$ & 1.406 & 3.949 & 146 & 1.226 & 20.9 & 58.7 & 2.2 & 18.2 \\
\hline $\mathbf{2 0 0 8}$ & 1.334 & 3.817 & 127 & 1.067 & 21 & 60.2 & 2.0 & 16.8 \\
\hline $\mathbf{2 0 0 9}$ & 1.274 & 3.474 & 94 & 1.107 & 21.4 & 58.4 & 1.6 & 18.6 \\
\hline $\mathbf{2 0 1 0}$ & 1.341 & 3.855 & 81 & 1.079 & 21.1 & 60.7 & 1.3 & 17 \\
\hline $\mathbf{2 0 1 1}$ & 1.307 & 3.794 & 118 & 1.079 & 20.7 & 60.7 & 1.9 & 17.1 \\
\hline $\mathbf{2 0 1 2}$ & 1.336 & 3.866 & 116 & 1.167 & 20.6 & 59.6 & 1.8 & 18 \\
\hline
\end{tabular}

Kaynak: ECB “The International Role of Euro” July 2013 s.77

Tablo 6'da ise para birimlerine göre uluslararası bono ve senet miktarı verilmektedir. Bu tablo genel anlamda değerlendirildiğinde kriz sonrası yıllarda çoğu ülke para birimi cinsinden tutulan bono 
ve senet miktarında düşüşler olduğu görülmektedir. Buna rağmen, sabit oranlı ve değişen oranlı olarak tutulan bono ve senet miktarında Euro ilk sıradaki yerini korumaktadır. Bu durum yine yatırımciların Euro cinsinden varlık tutmaya, yatırım yapmaya ve güvenlerini sürdürmeye devam ettiklerinin bir göstergesidir.

Tablo 6. Para Birimlerine Göre Uluslararası Bono ve Senet Miktarı (Milyar \$)

\begin{tabular}{|c|c|c|c|c|c|c|c|c|c|c|}
\hline $\begin{array}{l}\text { Değişen } \\
\text { Oranlı }\end{array}$ & 2004 & 2005 & 2006 & 2007 & 2008 & 2009 & 2010 & 2011 & 2012 & 2013* \\
\hline Dolar & 1124,1 & 1205,1 & 1676,9 & 2053,6 & 2227,6 & 2256,5 & 2166,7 & 1510,8 & 1466,5 & 1504,4 \\
\hline Euro & 2070,7 & 2222,4 & 3179,6 & 4176,9 & 4463,8 & 4664,2 & 4305,8 & 3522 & 3291,2 & 3132 \\
\hline Yen & 110,1 & 91,7 & 92,2 & 126,2 & 178,2 & 181,1 & 194,8 & 186,1 & 143,2 & 105,9 \\
\hline Sterlin & 263,2 & 323,9 & 473,9 & 577,9 & 812,4 & 991,5 & 945,3 & 852 & 803,2 & 785,2 \\
\hline $\begin{array}{l}\text { İsviçre } \\
\text { Frank1 }\end{array}$ & 24,1 & 18,5 & 26,9 & 30,1 & 28,9 & 23,3 & 23,3 & 23 & 28 & 24,3 \\
\hline $\begin{array}{l}\text { Kanada } \\
\text { Dolar1 }\end{array}$ & 13,6 & 25 & 28,9 & 38,1 & 26,4 & 30 & 32 & 35,7 & 38,6 & 36,5 \\
\hline Diğer & 49,8 & 72,7 & 114,7 & 169,9 & 157 & 201,5 & 220,5 & 209,3 & 218,6 & 200,9 \\
\hline \multicolumn{11}{|l|}{$\begin{array}{l}\text { Sabit } \\
\text { Oranlı }\end{array}$} \\
\hline Dolar & 3656,2 & 4036,9 & 4576,5 & 5326,3 & 5833,4 & 6969,9 & 8090,4 & 4957,7 & 5573,6 & 5884,8 \\
\hline Euro & 4010,3 & 3977,1 & 5016,3 & 6219,2 & 6297,9 & 7590,4 & 7381,2 & 5751,2 & 6239,3 & 6086,4 \\
\hline Yen & 375,8 & 341,7 & 347,5 & 401,9 & 505,7 & 461,7 & 513 & 518,2 & 467,3 & 384,9 \\
\hline Sterlin & 707,2 & 727,1 & 965,1 & 1118,3 & 882,6 & 1143 & 1137,8 & 1046,8 & 1149,3 & 1138,9 \\
\hline $\begin{array}{l}\text { İsviçre } \\
\text { Frank1 }\end{array}$ & 189,7 & 181,6 & 217 & 259,4 & 294,2 & 332,8 & 371,8 & 354 & 345,9 & 328,4 \\
\hline $\begin{array}{l}\text { Kanada } \\
\text { Dolar1 }\end{array}$ & 98,4 & 121,1 & 148,3 & 225,2 & 210,1 & 269,3 & 308,4 & 267,6 & 238,3 & 209,7 \\
\hline Diğer & 248,5 & 296,8 & 361,2 & 457,2 & 408,6 & 500,1 & 596,3 & 640,2 & 756,3 & 751,8 \\
\hline \multicolumn{11}{|c|}{$\begin{array}{l}\text { Hisse } \\
\text { Senedi } \\
\text { Bağlantılı }\end{array}$} \\
\hline Dolar & 144,9 & 139,1 & 147,2 & 159,5 & 163,6 & 196,6 & 244,4 & 172,1 & 168 & 181,5 \\
\hline Euro & 143,5 & 114 & 114,2 & 134,8 & 113,3 & 123,3 & 107,2 & 54 & 54,2 & 64,8 \\
\hline Yen & 45 & 38,7 & 47,6 & 49,5 & 63,9 & 51,2 & 52,5 & 37,5 & 34,8 & 28,4 \\
\hline Sterlin & 12,2 & 12 & 10,9 & 8,4 & 7,8 & 7,7 & 8,7 & 6,6 & 6,3 & 6 \\
\hline $\begin{array}{l}\text { İsviçre } \\
\text { Frank1 }\end{array}$ & 14,7 & 8,6 & 10 & 12 & 8,6 & 9,4 & 6,1 & 3,7 & 6,1 & 1,2 \\
\hline $\begin{array}{l}\text { Kanada } \\
\text { Dolar1 }\end{array}$ & 0,6 & 0,6 & 0,8 & 2,9 & 3,7 & 7,4 & 11,8 & 8,3 & 10,1 & 10,5 \\
\hline Diğer & 8,7 & 9,6 & 13,3 & 30,3 & 42,3 & 48,2 & 54,4 & 44,4 & 39,7 & 37,1 \\
\hline
\end{tabular}

Kaynak: BIS Quarterly Review raporlarından derlenmiştir *2013 Temmuz 
Uluslararası özel ve kamu yatırımcılarının portföylerinde Euro'nun ağırlı̆̆ı halen devam etmektedir. Avrupa krizinin derinleşmeye başladığı zamanlarda bile Euro'nun dolar karşısındaki değerinin beklendiği kadar düşmemesi, halen Euro'nun yatırım parası olarak önemini koruduğunun ve yatırımcıların Euro'ya bakışının bir sonucudur.

\section{2. Rezerv Para Olarak Euro}

Bir para biriminin, uluslararası para birimi olabilmesi için rezerv para olarak tercih edilmesi önemli bir unsurdur. Özellikle, ülke merkez bankalarının o para cinsinden tuttukları rezervler, dünya ekonomisinde o paranın yerini ve önemini belirlemektedir. $\mathrm{Bu}$ açıdan dünya ekonomisine bakıldığında, geçmişten beri Doların hakimiyeti görülmektedir. İkinci Dünya Savaşı'ndan ve Bretton Woods Sistemi’nin uygulandığı yıllardan günümüze kadar dünyadaki merkez bankaları döviz rezervlerinin çok büyük bir bölümünü Dolar cinsinden tutmaktadırlar.

Merkez bankaları, işlem ve ihtiyat nedenleriyle rezerv bulundurdukları gibi, beklenmedik, yani spekülatif harekete hazır olmak için de rezerv tutarlar. Merkez bankalarının tutacağı rezerv miktarını ve bileşimini belirleyen üç unsur vardır. Bunlar (Savaş, 1999:168-169):

- Ülkenin izlediği döviz kuru politikası,

- Ülkenin ticari ilişkilerinin yönü ve kullanılan para türlerinin bileşimi,

- Ülke borçlarının belirlendiği para birimi veya birimleridir.

$\mathrm{Bu}$ unsurlar incelendiğinde Doların neden önemli bir rezerv para olduğu daha iyi anlaşılabilir. Çünkü geçmişten günümüze uluslararası fiyatlandırmada ve ticarette Doların ağırlığı çok fazladır. Ülkelerin borçları da Dolar ile ölçülmektedir. Doların dünya piyasasındaki bu hâkimiyetinden dolayı, Euro'nun yürürlüğe girmesinden önce, bir rezerv para niteliği taşıyıp taşıyamayacağı merak edilmekteydi. Euro dolaşıma çıkmadan önce, dünyadaki döviz rezervlerinin bileşimi Tablo 7'de gösterilmektedir.

Tablo 7. Euro'nun Dolaşımından Önce Dünyadaki Resmi Rezervlerin Bileşimi (\%)

\begin{tabular}{|l|c|c|c|c|c|c|c|c|c|c|}
\hline Para cinsi & $\mathbf{1 9 8 9}$ & $\mathbf{1 9 9 0}$ & $\mathbf{1 9 9 1}$ & $\mathbf{1 9 9 2}$ & $\mathbf{1 9 9 3}$ & $\mathbf{1 9 9 4}$ & $\mathbf{1 9 9 5}$ & $\mathbf{1 9 9 6}$ & $\mathbf{1 9 9 7}$ & $\mathbf{1 9 9 8}$ \\
\hline ABD Doları & 51.3 & 47.8 & 48.3 & 51.9 & 53.0 & 53.0 & 54.0 & 56.9 & 57.1 & 60.3 \\
\hline Japon Yeni & 7.2 & 7.7 & 8.3 & 7.3 & 7.3 & 7.5 & 6.2 & 5.5 & 4.8 & 5.1 \\
\hline İng. Sterlini & 2.3 & 2.8 & 3.1 & 2.9 & 2.8 & 3.1 & 3.0 & 3.2 & 3.3 & 3.9 \\
\hline Alm. Markı & 17.8 & 16.5 & 15.1 & 13.0 & 13.4 & 13.8 & 13.2 & 12.5 & 12.3 & 12.1 \\
\hline Fra. Frankı & 1.4 & 1.2 & 1.1 & 1.0 & 1.1 & 0.9 & 0.7 & 0.7 & 0.6 & 0.7 \\
\hline Hol. Guldeni & 1.1 & 1.0 & 1.0 & 0.6 & 0.6 & 0.5 & 0.4 & 0.3 & 0.4 & 0.4 \\
\hline Diğerleri & 6.7 & 11.1 & 10.2 & 11.3 & 11.6 & 11.3 & 13.5 & 13.2 & 15.1 & 15.5 \\
\hline
\end{tabular}

Kaynak: IMF Annual Report 1999, s:133 
Tablo 7'ye bakıldığında 1989'dan 1998'e kadar ABD Dolarının toplam rezervler içindeki payının giderek arttığı görülmektedir. Buna karşın, Alman markının döviz rezervleri içindeki payı azalmıştır. Şu anda AB'ye üye olan ve Euro alanına dahil olan Fransa ve Hollanda'nın resmi paralarının payı ise oldukça düşük düzeydedir. Euro'ya geçilmesinden sonra dünya rezervlerindeki değişim ise Tablo 8'de gösterilmektedir. Euro'ya geçilmesinden sonraki sürece bakıldığında Euro'nun toplam rezervler içindeki payının 2009 yılına kadar sürekli bir artış içinde olduğu görülmektedir. 2009 yılından sonra az da olsa bir azalış olmasına rağmen, Avrupa Birliği’ndeki kriz ve bu krizin derinliği düşünüldüğünde bu azalma çok da önemli düzeyde değildir.

Tablo 8. Euro'ya Geçişten Sonra Dünyadaki Resmi Rezervlerin Bileşimi (\%)

\begin{tabular}{|c|c|c|c|c|c|c|c|c|c|c|c|}
\hline Para Cinsi & 2001 & 2002 & 2003 & 2004 & 2005 & 2006 & 2007 & 2008 & 2009 & 2010 & 2011 \\
\hline \multicolumn{12}{|l|}{ Bütün Ülkeler } \\
\hline ABD Doları & 71.5 & 67.1 & 65.9 & 65.9 & 66.9 & 65.5 & 64.1 & 64.1 & 62 & 61.8 & 62.2 \\
\hline Euro & 19.2 & 23.8 & 25.2 & 24.8 & 24.1 & 25.1 & 26.3 & 26.4 & 27.7 & 26 & 25 \\
\hline Japon Yeni & 5 & 4.4 & 3.9 & 3.8 & 3.6 & 3.1 & 2.9 & 3.1 & 2.9 & 3.7 & 3.5 \\
\hline İngiliz Sterlini & 2.7 & 2.8 & 2.8 & 3.4 & 3.6 & 4.4 & 4.7 & 4.0 & 4.2 & 3.9 & 3.8 \\
\hline İsviçre Frangı & 0.3 & 0.4 & 0.2 & 0.2 & 0.1 & 0.2 & 0.2 & 0.1 & 0.1 & 0.1 & 0.1 \\
\hline Diğerleri & 1.3 & 1.6 & 2 & 1.9 & 1.7 & 1.8 & 1.8 & 2.2 & 3.0 & 4.4 & 5.3 \\
\hline \multicolumn{12}{|l|}{ Gelişmiş Ülkeler } \\
\hline ABD Doları & 70.5 & 66.4 & 67.1 & 67.3 & 69.2 & 68.1 & 66 & 67.1 & 65.1 & 65 & 66.3 \\
\hline Euro & 19 & 23.3 & 23.1 & 22.9 & 21.2 & 22.2 & 24.2 & 23.3 & 25.4 & 23.9 & 22.9 \\
\hline Japon Yeni & 6.1 & 5.4 & 5.2 & 5 & 4.7 & 4.2 & 4 & 4.3 & 3.9 & 4.5 & 4.2 \\
\hline İngiliz Sterlini & 2.7 & 2.8 & 2.3 & 2.7 & 2.7 & 3.3 & 3.5 & 2.7 & 2.8 & 2.5 & 2.5 \\
\hline İsviçre Frangı & 0.3 & 0.5 & 0.3 & 0.2 & 0.2 & 0.2 & 0.2 & 0.2 & 0.2 & 0.2 & 0.2 \\
\hline Diğerleri & 1.4 & 1.6 & 2.1 & 2.1 & 1.9 & 1.9 & 2.1 & 2.5 & 2.6 & 3.9 & 3.9 \\
\hline \multicolumn{12}{|c|}{$\begin{array}{l}\text { Gelişmekte Olan } \\
\text { Ülkeler }\end{array}$} \\
\hline ABD Doları & 73.9 & 68.7 & 63.2 & 63.1 & 62.8 & 61.6 & 62.1 & 60.8 & 58.6 & 58.3 & 57.6 \\
\hline Euro & 19.6 & 25.1 & 30.1 & 29.1 & 29 & 29.4 & 28.5 & 29.9 & 30.2 & 28.3 & 27.4 \\
\hline Japon Yeni & 2.4 & 1.7 & 1.1 & 1.3 & 1.5 & 1.3 & 1.8 & 1.9 & 1.8 & 2.8 & 2.7 \\
\hline İngiliz Sterlini & 2.8 & 2.8 & 3.8 & 4.9 & 5.1 & 6 & 5.9 & 5.5 & 5.9 & 5.5 & 5.3 \\
\hline İsviçre Frangı & 0.2 & 0.1 & 0.1 & 0.1 & 0.1 & 0.1 & 0.1 & 0.1 & 0 & 0.1 & 0.1 \\
\hline Diğerleri & 1 & 1.5 & 1.8 & 1.4 & 1.5 & 1.6 & 1.5 & 1.9 & 3.5 & 5 & 6.9 \\
\hline
\end{tabular}

Kaynak: IMF Annual Report 2012 Appendix 1, s:6

Tablo 8'e gelişmekte olan ülkeler özelinde bakıldığında durum daha dikkat çekicidir. Gelişmekte olan ülkelerin resmi döviz rezervleri içerisinde Amerikan Dolarının payı 2001 yılından itibaren sürekli azalmakta iken Euro'nun payı ise 2001-2009 yılları arasında bir artış içerisindedir. Çıktığı andan itibaren rezervlerde bulundurulmaya başlanan Euro, Avrupa Birliği'nin içinde bulunduğu borç krizine rağmen rezerv para olma niteliğini korumaktadır. Çin, Japonya ve bazı asya 
ülkelerinin rezervlerinin bir kısmını Euro olarak tutacaklarına devam edeceklerini açıklamaları Euro'nun rezerv para olma niteliğinin devam ettiğinin bir göstergesidir. Rezerv para olarak Euro'nun bundan sonraki durumu; Euro alanının istikrarına, ekonomik gücüne, Amerika ve Avrupa ekonomilerindeki krizin izleyeceği sürece bağlı olarak şekillenecektir.

\section{3. Mübadele Parası Olarak Euro}

AB'nin ulaştı̆̆1 son noktadaki boyutunu düşünürsek Euro'nun ne kadar büyük alanda dolaştığı daha iyi anlaşılmaktadır. Fiili anlamda 17 ülkenin yanında, 6 ülkede Euro alanına dahil olmadıkları halde kendi para birimleri olarak Euro’yu kullanmaktadır. Bu açıdan düşünüldüğünde, Euro çok büyük bir alanda dolaşımda bulunmakta ve çeşitli işlemlerde mübadele parası olarak kullanılmaktadır. Ancak bir paranın mübadele kapsamı sadece çıkarıldığı bölgeyle sınırlı kalmamalıdır. Euro'nun uluslararası ticarette kullanımı AB'nin yaptığı ticaretle de doğrudan ilişkilidir. Özellikle, Euro alanı ülkeleriyle ticarette bulunan ülkelerbu bölgedeki fiyatların Euro'yla ifade edilmeye başlanmasından itibaren alışverişlerini Euro kullanarak yapmaya başlamışlardır. AB'nin kendi içindeki ticarette de Euro'yu kullanması, Euro'nun mübadele parası olmasını kolaylaştırmıştır. Ayrıca, eski Fransız sömürgesi olan bazı Afrika ülkeleri ve Euro alanına katılmak isteyen ve bunun için Döviz Kuru Mekanizması 2 (DKM2) dahil olmuş veya yakın gelecekte dahil olacak yeni AB üyeleri de Euro'yu baz alarak hareket etmektedirler.

$\mathrm{AB}$ halen dünyadaki en önemli ticari güçtür. $\mathrm{AB}$ 'nin dünya mal ticareti içerisindeki payı \%32,2'dir. Avrupa Birliğini, \%10,8'lük payla ABD ve \%10.7 payla Çin takip etmektedir. (World Trade Report 2012:32).Uluslararası ticarette ve ödemelerde kullanılan parayla ilgili kapsamlı bir istatistik yoktur. Ticaret işlemleri platformunu kullanarak işlemlerini gerçekleştirenleri kaydeden Dünya Bankalararası Mali Telekomünikasyon Derneği (SWIFT) tarafından sağlanan verilere göre döviz piyasasındaki tüm işlemlerin \%45'i ABD Doları cinsinden, \%20'si ise Euro cinsinden yapılmaktadır (WTO, 2012:11).Avrupa ile Amerika arasında imzalanması düşünülen serbest ticaret anlaşmasının yürürlüğe girmesinden sonra uluslararası ticarete yeni bir boyut getirmesi ve uluslararası ticarette Euro'nun önemini daha da artırması beklenilebilir. Buradan hareketle, Euro'nun bir mübadele parası olma niteliğini devam ettirdiği ve Euro'dan vazgeçilmezse bu niteliğini gelecekte artıracağ 1 sonucuna var1labilir.

\section{4. Kur Belirleme Standardı Olarak Euro}

Euro'ya geçilmeden önce Euro'nun kur belirleme özelliğinin olup olmayacağı merak konusu unsurlar arasındaydı. Bunu gidermek amacıyla ilk aşamada parasal birliğe katılmayan Avrupa Birliği ülkeleri için merkezinde Euro olan bir düzenleme yapıldı. AB'nin 25 üyeli bir hal almasıyla beraber. Euro alanı dışında kalan ancak ileride parasal birliğe dahil olmak isteyen potansiyel parasal birlik ülkeleri için Euro yüksek düzeyde çekiciliğe sahip oldu (Birinci, 2001:77). Bu ülkeler, Euro kurundaki değişmeleri yakından takip eder hale geldiler. 
2000 yılından itibaren forex piyasalarda büyük gelişimler yaşanmıştır. Forex piyasaları farklı ülkelerin paralarının birbiriyle değiştirildiği kaldıraçlı bir döviz piyasasıdır. Forex piyasalarında dövizler arasında değişim temel alınsa da, bu piyasanın beklenenden daha fazla ilgi görmesi sonucunda altın, gümüş gibi değerli metallerin dışında petrol ve farklı borsalara ilişkin endekslerde de işleme girilebilme özelliğine sahiptir. Dünyanın en büyük finansal piyasası olma özelliğine sahip bu piyasanın işlem hacmi,2007'de 3.3 trilyon dolar iken 2010'da 4 trilyon dolar olmuş 2013'de ise bu rakamın 5.5 trilyon dolar seviyesine yükseldiği tahmin edilmektedir. Hızlı bir büyüme içerisinde olan bu piyasada üzerinde en fazla işlem yapılan ürün ise Euro-Dolar paritesidir(BIS Report, 2013). Bu açılardan bakıldığında Euro, dünyada milyonlarca yatırımcının yakından takip ettiği bir para birimidir.

Tablo 9'da küresel döviz piyasalarında işlem gören para birimlerinin payları gösterilmektedir. Amerikan dolarının bu piyasadaki ağırlığına rağmen (\%87), Euro’nun da azımsanmayacak bir ağırlığa (\%33) sahip olduğu söylenebilir. Bu piyasadaki gelişmelere paralel olarak dünyanın tek kutuplu (Dolar) merkezden çıkarak iki kutuplu (Euro-Dolar) bir hal aldığı söylenebilir.

Tablo 9. Küresel Döviz Piyasalarında Para Birimlerinin Payları *

\begin{tabular}{|l|c|c|c|c|c|c|}
\hline Para Birimi & $\mathbf{1 9 9 8}$ & $\mathbf{2 0 0 1}$ & $\mathbf{2 0 0 4}$ & $\mathbf{2 0 0 7}$ & $\mathbf{2 0 1 0}$ & $\mathbf{2 0 1 3}$ \\
\hline Amerikan Doları & 86,8 & 89,9 & 88,0 & 85,6 & 84,9 & 87,0 \\
\hline Euro & $\ldots$ & 37,9 & 37,4 & 37,0 & 39,1 & 33,4 \\
\hline Japon Yeni & 21,7 & 23,5 & 20,8 & 17,2 & 19,0 & 23,0 \\
\hline İngiliz Sterlini & 11,0 & 13,0 & 16,5 & 14,9 & 12,9 & 11,8 \\
\hline Avusturalya Doları & 3,0 & 4,3 & 6,0 & 6,6 & 7,6 & 8,6 \\
\hline İsviçre Frang1 & 7,1 & 6,0 & 6,0 & 6,8 & 6,3 & 5,2 \\
\hline Kanada Doları & 3,5 & 4,5 & 4,2 & 4,3 & 5,3 & 4,6 \\
\hline Meksika Pezosu & 0,5 & 0,8 & 1,1 & 1,3 & 1,3 & 2,5 \\
\hline Çin Renminbi & 0,0 & 0,0 & 0,1 & 0,5 & 0,9 & 2,2 \\
\hline Yeni Zelanda Doları & 0,2 & 0,6 & 1,1 & 1,9 & 1,6 & 2,0 \\
\hline İsveç Kronası & 0,3 & 2,5 & 2,2 & 2,7 & 2,2 & 1,8 \\
\hline Rusya Rublesi & 0,3 & 0,3 & 0,6 & 0,7 & 0,9 & 1,6 \\
\hline Türk Lirası & 0,0 & 0,0 & 0,1 & 0,2 & 0,7 & 1,3 \\
\hline Diğer & 4,4 & 16,7 & 15,8 & 20,4 & 17,8 & 14,9 \\
\hline Toplam & $\mathbf{2 0 0 , 0}$ & $\mathbf{2 0 0 , 0}$ & $\mathbf{2 0 0 , 0}$ & $\mathbf{2 0 0 , 0}$ & $\mathbf{2 0 0 , 0}$ & $\mathbf{2 0 0 , 0}$ \\
\hline
\end{tabular}

Kaynak: BIS Report 2013, s:10

*Her döviz işleminde iki cins para kullanıldığ için yüzde toplamı \%100 yerine \%200 olarak hesaplanmaktadır.

Özellikle, Euro'nun portföylerde daha fazla yer almasından sonra dünya finans piyasaları Euro/Dolar kurunu daha yakından izlemektedirler. Euro/Dolar kurundaki değişim Şekil 1'de görülmektedir. Bu dönemde Euro/Dolar paritesi en düşük 0,88 seviyelerini en yüksek ise 1,55 seviyelerini görmüştür. Euro'nun ilk çıktığı yıllarda Dolar karşısında değerinin düşmesine karşılık 
daha sonraki yıllarda faiz oranları farklılığı ve ABD'de süre gelen dış ticaret açıları nedeniyle değerinin yükseldiği görülmektedir. Bu dönemde, Euro'nun rezerv para olarak tercih edilmeye başlaması da değer kazanmasını hızlandıran bir başka unsur olmuştur. Son zamanlarda ise AB'deki büyümenin yavaşlayacağı endişesiyle Euro'nun Dolar karşısındaki değerinde bir gerileme yaşanmaktadır. Ayrıca, son zamanlarda parite üzerinde etkili olan diğer hususlar: Amerikan ve Avrupa merkez bankalarının kriz karşısında uygulamaya koydukları genişlemeci politikalar ile ülkelerdeki makro ekonomik göstergelerdir.

Şekil 1. Euro/Dolar Paritesinin Gelişimi (Ocak 1999-Mayıs 2013)

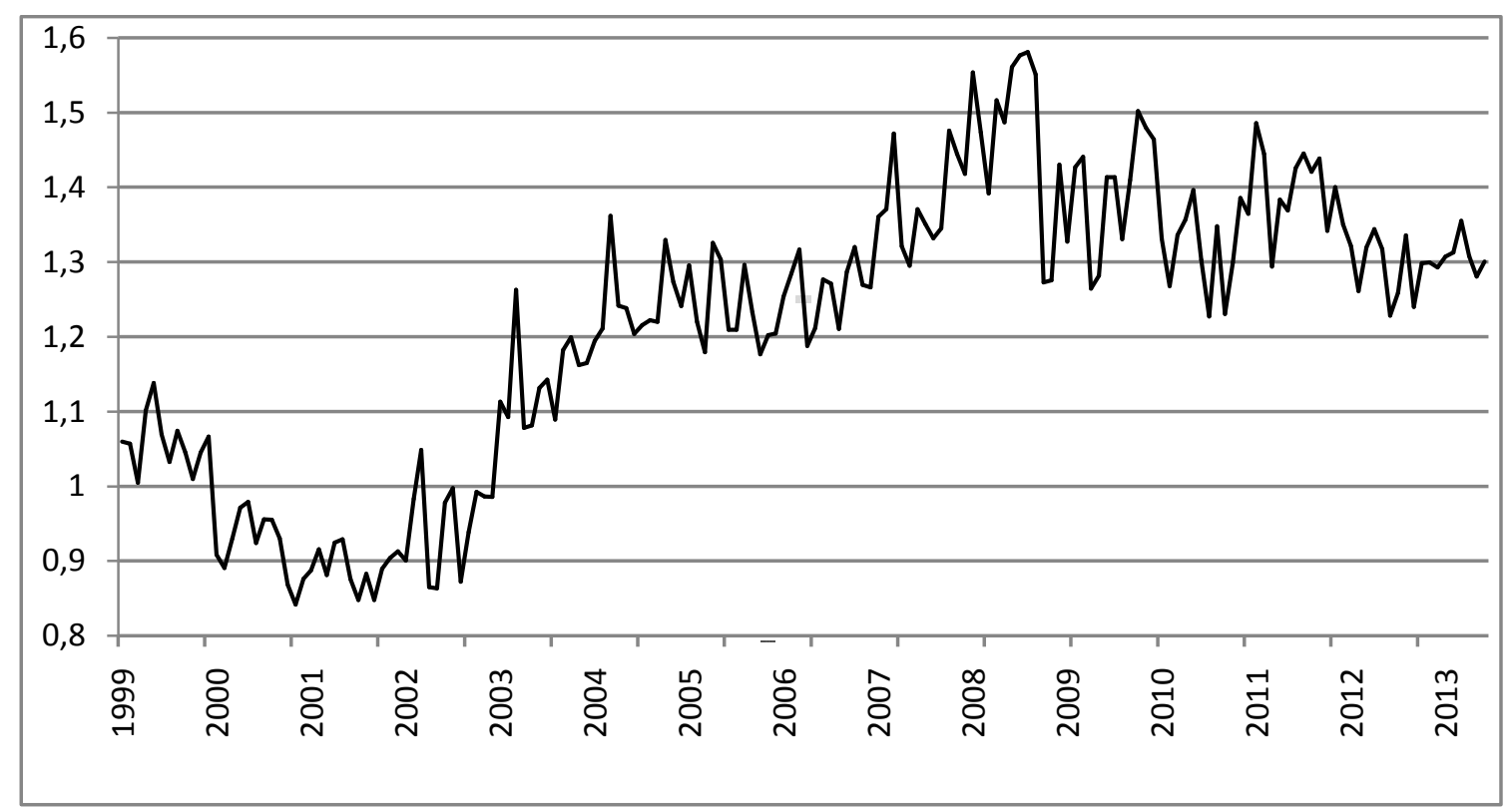

Kaynak: ECB Statistical Data Ware House (http://sdw.ecb.europa.eu/browse.do?node=2018794)

Euro'nun yürürlüğe konmasından sonra, uluslararası sistemde geçmişten beri süregelen Dolar bazlı (tek kutuplu) sistem ortadan kalkmış ve yerini iki kutuplu bir sisteme bırakmıştır. Amerika ekonomisinin toparlanmaya başlaması, Avrupa'daki sorunların devam etmesine rağmen Euro'nun Dolar karşısında değerini koruması Euro'nun dünyada tercih edildiğinin bir göstergesi olması yanında Euro'nun geleceği açısından olumlu bir gelişme olarak değerlendirilebilir. Bu bağlamda, Euro'nun kur belirleme standardı niteliğini krize rağmen devam ettirdiği görülmektedir.

\section{EURO’NUN GELECEĞİNE YÖNELIKK OLASILIKLAR}

Avrupa Birliği’nin içinde bulunduğu kriz ve bu krizin her gün yeni bir boyut kazanması, ekonomi çevrelerinde ister istemez Euro ve geleceği ile ilgili şüpheleri artırmaktadır. Tablo 10'da Euro'nun geleceğini şekillendirecek ulusal boyuttaki, Avrupa boyutundaki ve uluslararası boyuttaki ana faktörlere yer verilmiştir. 
Tablo 10. Ekonomik ve Parasal Birliğin Geleceğini Şekillendirecek Ana Faktörler

\begin{tabular}{|c|c|c|c|c|c|c|}
\hline BOYUTLAR & $\begin{array}{l}\text { Parasal } \\
\text { Faktörler }\end{array}$ & $\begin{array}{l}\text { Finansal } \\
\text { Faktörler }\end{array}$ & $\begin{array}{l}\text { Bütçe } \\
\text { Finansmanı }\end{array}$ & $\begin{array}{l}\text { Ekonomik } \\
\text { Faktörler }\end{array}$ & $\begin{array}{l}\text { Sosyal } \\
\text { Faktörler }\end{array}$ & $\begin{array}{l}\text { Politik } \\
\text { Faktörler }\end{array}$ \\
\hline \multirow[t]{7}{*}{ Ulusal } & $\begin{array}{l}\text { Faiz } \\
\text { Oranlar1 }\end{array}$ & Kredi Desteği & $\begin{array}{l}\text { Bütçe } \\
\text { Açı̆̆ı/GSYİH }\end{array}$ & $\begin{array}{l}\text { Büyüme } \\
\text { Oranları }\end{array}$ & $\begin{array}{l}\text { İşsizlik } \\
\text { Oranı }\end{array}$ & $\begin{array}{l}\text { Ulusal Mali } \\
\text { Egemenlik }\end{array}$ \\
\hline & $\begin{array}{l}\text { Enflasyon } \\
\text { Oranları }\end{array}$ & $\begin{array}{l}\text { Bankalararası } \\
\text { Borç Verme }\end{array}$ & $\begin{array}{l}\text { Kamu } \\
\text { Borcu/GSYİH }\end{array}$ & $\begin{array}{l}\text { İşsizlik } \\
\text { Oranları }\end{array}$ & $\begin{array}{l}\text { Yoksulluk } \\
\text { Oranı }\end{array}$ & Hükümetler \\
\hline & $\begin{array}{l}\text { Merkez } \\
\text { Bankaları }\end{array}$ & $\begin{array}{l}\text { Ulusal } \\
\text { Bankaların } \\
\text { Gelişimi }\end{array}$ & $\begin{array}{l}\text { Kamu } \\
\text { Yatırımları }\end{array}$ & $\begin{array}{l}\text { İşgücü Birim } \\
\text { Maliyetleri }\end{array}$ & $\begin{array}{l}\text { Eğitim } \\
\text { Düzeyi }\end{array}$ & Parlamentolar \\
\hline & & $\begin{array}{l}\text { Diğer Finansal } \\
\text { Operatörler }\end{array}$ & $\begin{array}{l}\text { Sosyal } \\
\text { Harcamalar }\end{array}$ & $\begin{array}{l}\text { İhracat, } \\
\text { İthalat }\end{array}$ & $\begin{array}{l}\text { Emeklilik } \\
\text { Yaş1 }\end{array}$ & \\
\hline & & Özkaynaklar & $\begin{array}{l}\text { İstikrar ve } \\
\text { Yakınlaşma } \\
\text { Programları }\end{array}$ & $\begin{array}{l}\text { Pazar } \\
\text { Payları }\end{array}$ & $\begin{array}{l}\text { Ücret } \\
\text { Düzeyi }\end{array}$ & \\
\hline & & Hedge Fonlar & $\begin{array}{l}\text { Bütçe } \\
\text { Disiplini }\end{array}$ & $\begin{array}{l}\text { Cari } \\
\text { Hesaplar }\end{array}$ & $\begin{array}{l}\text { Toplu } \\
\text { Pazarlık }\end{array}$ & \\
\hline & & $\begin{array}{l}\text { Büyük } \\
\text { Bankaların } \\
\text { Durumu }\end{array}$ & & $\begin{array}{l}\text { Ulusal } \\
\text { Reform } \\
\text { Programları }\end{array}$ & & \\
\hline \multirow[t]{7}{*}{ Avrupa } & $\begin{array}{l}\text { Faiz } \\
\text { Oranlar1 }\end{array}$ & $\begin{array}{l}\text { Borsa } \\
\text { Göstergeleri }\end{array}$ & $\begin{array}{l}\text { Bütçe Açığ } 1 \\
\text { Sinırı }\end{array}$ & $\begin{array}{l}\text { İhracat, } \\
\text { İthalat }\end{array}$ & $\begin{array}{l}\text { İşsizlik } \\
\text { Oranı }\end{array}$ & $\begin{array}{l}\text { AB Bütçe } \\
\text { Koordinasyonu }\end{array}$ \\
\hline & $\begin{array}{l}\text { Enflasyon } \\
\text { Oranları }\end{array}$ & $\begin{array}{l}\text { Bankalararas1 } \\
\text { Borç Verme }\end{array}$ & $\begin{array}{l}\text { Kamu Borcu } \\
\text { Sinırı }\end{array}$ & $\begin{array}{l}\text { Büyüme } \\
\text { Oranları }\end{array}$ & $\begin{array}{l}\text { Yoksulluk } \\
\text { Oranı }\end{array}$ & $\begin{array}{l}\text { AB Bütçe } \\
\text { Koordinasyonu }\end{array}$ \\
\hline & Parite & $\begin{array}{l}\text { Avrupa Yatırım } \\
\text { Bankas1 }\end{array}$ & $\begin{array}{l}\text { Orta Vadeli } \\
\text { Hedefler }\end{array}$ & $\begin{array}{l}\text { İşsizlik } \\
\text { Oranları }\end{array}$ & $\begin{array}{l}\text { Eğitim } \\
\text { Düzeyi }\end{array}$ & $\begin{array}{l}\text { AB Mali } \\
\text { Otoritesi }\end{array}$ \\
\hline & AMB & $\begin{array}{l}\text { Finansal } \\
\text { Düzenlemeler }\end{array}$ & $\begin{array}{l}\text { İstikrar ve } \\
\text { Büyüme Pakt1 }\end{array}$ & $\begin{array}{l}\text { Makro- } \\
\text { Ekonomik } \\
\text { Gözetim }\end{array}$ & $\begin{array}{l}\text { İstihdam } \\
\text { Kurallar1 }\end{array}$ & $\begin{array}{l}\text { AB Ekonomik } \\
\text { ve Sosyal } \\
\text { Politikalar } \\
\text { Koordinasyonu }\end{array}$ \\
\hline & & $\begin{array}{l}\text { Avrupa Mali } \\
\text { Denetim } \\
\text { Organlar1 }\end{array}$ & $\begin{array}{l}\text { Oylama ve } \\
\text { Kontrol } \\
\text { Yöntemleri }\end{array}$ & $\begin{array}{l}\text { Avrupa } 2020 \\
\text { Stratejisi }\end{array}$ & & $\begin{array}{l}\text { Avrupa } \\
\text { Konseyi, } \\
\text { Avrupa } \\
\text { Komisyonu }\end{array}$ \\
\hline & & EFSF/ESM & $\begin{array}{l}\text { Topluluk } \\
\text { Bütçesi }\end{array}$ & $\begin{array}{l}\text { Avrupa } \\
\text { Yatırım } \\
\text { Destek Planı }\end{array}$ & & $\begin{array}{l}\text { Avrupa } \\
\text { Parlementosu }\end{array}$ \\
\hline & & & $\begin{array}{l}\text { Harcama } \\
\text { Öncelikleri }\end{array}$ & & & $\begin{array}{l}\text { Avrupa } \\
\text { Seçimleri }\end{array}$ \\
\hline \multirow[t]{4}{*}{ Uluslararası } & $\begin{array}{l}\text { Faiz } \\
\text { Oranları }\end{array}$ & $\begin{array}{l}\text { Borsa } \\
\text { Göstergeleri }\end{array}$ & IMF & $\begin{array}{l}\text { Büyüme } \\
\text { Oranları }\end{array}$ & ILO & IMF \\
\hline & $\begin{array}{l}\text { Enflasyon } \\
\text { Oranları }\end{array}$ & $\begin{array}{l}\text { Finansal } \\
\text { Düzenlemeler }\end{array}$ & G20 & $\begin{array}{l}\text { Cari } \\
\text { Hesaplar }\end{array}$ & G20 & G20 \\
\hline & Kurlar & $\begin{array}{l}\text { Kredi } \\
\text { Derecelendirme } \\
\text { Kurumlar1 }\end{array}$ & & WTO & & \\
\hline & IMF & $\begin{array}{l}\text { Sermaye } \\
\text { Yatırımı Akışı }\end{array}$ & & G20 & & \\
\hline
\end{tabular}




\begin{tabular}{|l|l|l|l|l|l|l|}
\hline BOYUTLAR & $\begin{array}{l}\text { Parasal } \\
\text { Faktörler }\end{array}$ & $\begin{array}{l}\text { Finansal } \\
\text { Faktörler }\end{array}$ & $\begin{array}{l}\text { Bütçe } \\
\text { Finansmanı }\end{array}$ & $\begin{array}{l}\text { Ekonomik } \\
\text { Faktörler }\end{array}$ & $\begin{array}{l}\text { Sosyal } \\
\text { Faktörler }\end{array}$ & $\begin{array}{l}\text { Politik } \\
\text { Faktörler }\end{array}$ \\
\hline & G20 & $\begin{array}{l}\text { Yeni Spekülatif } \\
\text { Balonlar }\end{array}$ & & & & \\
\hline
\end{tabular}

Kaynak: Rodrigues, Maria João "Mapping Future Scenarios For The Eurozone” s.12

Avrupa krizinin her gün yeni bir boyut kazanması hem Euro hem de Euro bölgesi üzerindeki şüpheleri artırmakta ve geleceğe yönelik olarak çeşitli senaryoların ortaya konmasına sebep olmaktadır. Euro ve Euro bölgesi ile ilgili olarak bundan sonraki süreçte oluşabilecek muhtemel olasılıklar genel olarak 3 başlıkta toplanabilir. Bunlar: var olma, küçülme ve dağılmadır.

\section{1. OLASILIK 1: VAROLMA}

Euro'nun mevcut yapısını devam ettirmesi ve Euro bölgesinin bu krizden daha da güçlenerek çıkması ilk olasılık gibi görülmektedir. Ancak kamu borcunun GSYİH’ya oranı yüksek olan ülkelerin kemer sıkma önlemleri ile bu oranı azaltamamaları durumunda bu olasılık zora girmektedir. $\mathrm{Bu}$ olasılığın gerçekleşmesi; Almanya'nın borçluluk ve ekonomik yönetim konusundaki tutumunda köklü bir değişim gerektirmektedir (Curry ve Lynn, 2012:8)

Krizin derinleşmesinde ülkeler arasındaki makroekonomik farklılıklar rol oynamıştır. $\mathrm{Bu}$ noktada teşhisi doğru koymak gerekir. Sorulması gereken soru: bu makroekonomik farklıklar nereden kaynaklanıyor? Bu aşamada bu soruya cevap bulmak oldukça zor görünmektedir. Ancak İspanya, Yunanistan, İrlanda gibi ülkelerin reel faizlerinin Euro’ya girmelerinden dolayı düşmesi ve bu düşüşün daha sonra tüketim ve konut piyasalarında bir balon yaratarak patlamayı tetiklediği şeklinde yaygın bir görüş vardır. Bu durum kısmen doğru olmasına rağmen her şeyi açıklayamamaktadır (De Grauwe, 2010:5). Euro bölgesinin varlığını devam ettirebilmesi ve daha güçlü olabilmesi; bu sorunun yanıtının tam olarak bulunmasına ve ülkeler arasındaki makroekonomik farklılıkları giderecek önlemlerin alınmasına bağlıdır.

Var olma olasılı̆̆ı̆ güçlenmesi için Euro bölgesinin optimum para bölgesi olmasını engelleyen yapısal sıkıntıların ortadan kaldırılması, kapsamlı bir reform ve yeniden yapılanma sürecine girilmesi, bunun da kısa süre içerisinde gerçekleştirilmesi gerekecektir. İlk elden para ve maliye politikaları arasındaki uyumsuzluğun giderilmesi, mali alanda daha "merkezi” bir yönetişim sistemine geçilmesi ve "Avrupa Para Fonu" gibi mekanizmaların tesis edilerek finansal sistemin daha entegre bir şekilde yönetilmeye başlanması bu senaryoda ön plana çıkacak gelişmeler olacaktır (Usak Raporları, 2011:42).

Var olma olasılığını güçlendiren temel etkenler arasında AB'nin krizin daha fazla derinleşmemesi için şu ana kadar atmış olduğu adımlar yer almaktadır. Bu anlamda sağlanan fonlar Tablo 11'de daha net bir şekilde görülmektedir. Avrupa Merkez Bankası'nın piyasalara likidite desteği sağlamas1, EFSF (Avrupa Finansal İstikrar Fonu) ve IMF'in zorda olan ülkelere kredi desteği 
sağlaması ve Yunan tahvillerinin yeniden yapılandırılması ile sakinleşen krizden çıkış süreci, ülkelerin üzerlerine düşen yapısal reformları gerçekleştirmeleri ve kamu borcunun GSYIH'ya oranını azaltmaları ile daha iyiye doğru gidebilecektir.

Tablo 11. AB Krizinin Aşılması İçin Uygulamaya Koyulan Kurtarma Paketleri

\begin{tabular}{|l|c|c|c|}
\hline & $\begin{array}{c}\text { Tüm Ülkelerin Katkısı } \\
\text { (Milyar \$) }\end{array}$ & $\begin{array}{c}\text { Almanya'nın Katkısı } \\
\text { (Milyar \$) }\end{array}$ & $\begin{array}{c}\text { Fransa'nın Katkısı } \\
\text { (Milyar \$) }\end{array}$ \\
\hline $\begin{array}{l}\text { Avrupa Finansal } \\
\text { İstikrar Kurulu }\end{array}$ & 440 & 147,4 & 110,7 \\
\hline $\begin{array}{l}\text { Avrupa Finansal } \\
\text { Istikrar Mekanizması }\end{array}$ & 60 & 12 & 9,7 \\
\hline $\begin{array}{l}\text { IMF Euro Kurtarma } \\
\text { Planı }\end{array}$ & 250 & 14,9 & 12,3 \\
\hline $\begin{array}{l}\text { AB Yunanistan'ı } \\
\text { Kurtarma Planı }\end{array}$ & 80 & 22,3 & 16,8 \\
\hline $\begin{array}{l}\text { IMF Yunanistan'ı } \\
\text { Kurtarma Planı }\end{array}$ & 30 & 1,8 & 12,3 \\
\hline $\begin{array}{l}\text { AMB'nin Hükümet } \\
\text { Tahvillerini Satın } \\
\text { Alması }\end{array}$ & 60 & 16,4 & $\mathbf{1 6 3 , 3}$ \\
\hline TOPLAM & $\mathbf{9 2 0}$ & $\mathbf{2 1 4 , 9}$ & \\
\hline
\end{tabular}

Kaynak: Hans Werner Sinn “Rescuing Europe” CES ifo Forum Vol:11 August 2010 s:3.

$\mathrm{Bu}$ olasılığın gerçekleşmesi krizin mevcut durumundan çok daha kötüye gitmemesine krize müdahale önlemlerinin sonuç verip vermemesine mali reformların sürdürülebilirliğine ve piyasaların güven düzeyine bağlıdır (Ahearn, Jackson, Mix ve Nelson, 2012:20). Var olma olasıllı̆ının gerçekleşmesi halinde; yapısal sorunlarını çözmüş, mali, finansalve siyasal alanda daha fazla entegre olmuş ve bundan sonra ortaya çıkabilecek krizlere karşı daha dayanıklı bir Euro bölgesinden söz edilebilir. Ancak bu kriz, bazı reformlar göz ardı edilerek atlatılırsa, o zaman ileride yeniden Euro bölgesinin dağılması durumundan söz edilebilir.

\section{2. OLASILIK 2: KÜÇÜLME}

$\mathrm{Bu}$ olasılığa göre; ekonomik yapıları zayıflık gösteren ve bu zayıflığın uzun süre devam edeceğinin ortaya çıkmasıyla beraber para politikası uygulama yetisini geri kazanmak isteyen ülkelerin Euro'dan ayrılması, ekonomik yapısı daha güçlü ülkelerle daha küçük bir Euro grubunun oluşması söz konusudur. Bu durumda; aralarında İtalya, İspanya, Portekiz ve Yunanistan'ın da yer aldığı bazı ülkelerin para birliğinden ayrılması söz konusu olabilir ve kalan ülkelerle yola devam edilebilir.

Kriz öncesi dönemde, İspanya, Yunanistan ve Portekiz gibi ülkeler ekonomik büyümelerini sürdürebilmek için daha fazla dış kaynağa ihtiyaç duymuşlar ve \%10-15 düzeyinde cari açık vermişlerdir. Ancak Almanya başta olmak üzere kimi ülkeler büyük ölçüde cari fazla vermişlerdir. 
Kriz sonrası dönemde cari hesapları farklılık arz eden bu ülkelerin çözüm öncelikleri de değişik olmuştur. İspanya ve Yunanistan gibi ülkelerin kendi kaynaklarına dayanarak büyüyebilmesi için ya kur politikaları ya da mali politikalarında kapsamlı değişikliğe gitmesi gerekmektedir. (Usak Raporları, 2011: 17). Maliye politikaların uygulanması kamu sektörünün küçülmesi gibi sonuçlar doğurduğu için hem işsizlik üzerinde hem de büyüme üzerinde olumsuz etkilere yol açmaktadır. Diğer seçenek ise para politikasıdır. Ancak, bu ülkeler Euro bölgesinde olmalarından dolayı bu seçeneği henüz kullanamamaktadırlar. Bu ülkelerde krizin derinleşmesi, sosyal patlamaların artması sebebiyle krizden çıkışta para politikalarını aktif olarak kullanmak istemeleri halinde, Euro bölgesinin küçülme olasılığı güçlenecektir.

Bu ülkelerin Euro'dan çıkması durumunda, en büyük kazançları ulusal paralarını devalüe ederek, diğer Euro bölgesi ülkelerine karşı rekabet güçlerini artıracak olmalarıdır. Böylece, ihracatlarını artıracaklar, ithalatları azaltacaklar ve ihracat kaynaklı bir büyüme gerçekleştirebileceklerdir. Ancak Euro'dan çıkmanın bu ülkelere getireceği negatif etkilerde söz konusudur. İlk negatif etki; bu ülkelerin kendi para birimlerine geçmeleri, ulusal para cinsinden borçların miktarını yükseltecektir. İkincisi, ulusal paranın değerinin Euro karşısında düşeceği beklentisi ülkeden sermaye çıkışını hızlandırarak bu ülkeleri daha zor bir duruma itebilecektir (Ahearn vd., 2012:19).

Zaman zaman dillendirilen bir başka konuda sadece Yunanistan'ın birlikten çıkarılması ve Euro alanının kalan ülkelerle devam etmesidir. Yunanistan'ın ekonomik büyüklüğü Euro bölgesinin toplam ekonomik büyüklüğünün yalnızca \%2'sini oluşturmaktadır. Bu oran İspanya ya da İtalya ile kıyaslandığında çok düşüktür. Ancak, sorun sadece Yunanistan'ın ayrılması değil, Yunanistan'ın ayrılmasınınEuro bölgesindeki diğer riskli ülkelere negatif etkisinin artarak bu ülkeleri zora sokması ve bu ülkelere Yunanistan'ın örnek oluşturarak onlarında Euro'dan çıkış yönünde tavır almaları olacaktır.

$\mathrm{Bu}$ olasılığın gerçekleşmemesi için Yunanistan'ın kurtarılması gündeme gelmiştir. Bu amaçla Avrupa Birliği ve IMF Yunanistan'1 kurtarma planı kapsamında 110 milyar Euro'luk bir paket hazırlamışlardır. Buna ek olarak Avrupa Merkez Bankası çöp reytingine sahip Yunan devlet tahvillerini alacağını açıklamıştır. Bütün bunlara ek olarak $\mathrm{AB}$ ve $\mathrm{IMF}$ sorunlu ülkelerin kullanabilmesi için 750 milyar Euro'luk ek bir paket ortaya koymuştur (Bagus, 2010: 124-125).

\section{3. OLASILIK 3: DAĞILMA}

Avrupa Birliği'nin borç sorunlarını çözememesi, ülkeler arasındaki işbirliğinin azalması, krizin daha da derinleşmesi ve diğer ülkelere daha ağır sonuçlar oluşturmaya başlamasıyla ortaya çıabilecek bu olasılık; Euro alanına dahil bütün ülkelerin kendi para birimlerine geri dönmesi, üye ülkeler arasındaki paritenin dalgalanmaya bırakılması sonucunu doğuracaktır. 
Bu olasılığın gerçekleşmesi 1980’lerin Avrupa'sına dönüşten başka bir şey değildir. Başka bir deyişle $\mathrm{AB}$ kurumlarının bir dizi başarısızlığı anlamına gelmektedir. Bu sonuç; uzun bir süre $\mathrm{AB}$ ülkeleri arasındagüven erozyonuna yol açacaktır. Hatta AB'nin muhtemelen ekonomik, siyasi ve diplomatik anlamda çözülmesine doğru giden bir sürecin başlangıcı dahi olabilecektir (Curry ve Lynn, 2012:13).

Krizin aşılması ile ilgili olarak gelinen noktada bütçe sürecinde hiçbir değişiklik bulunmamaktadır. Topluluk bütçesinin kaynakları da yetersizdir. Korumacı bir tepki olarak bazı ülkeler Avrupa düzeyindeki programlarda ve ulusal bütçelerde daha yakın koordinasyonu reddetmektedirler. Bu tepki, ülkelerde ulusal paraya dönüş için bir baskı oluştururken Euro bölgesinin dağılmasının da önünü açmaktadır (Rodrigues, 2012:18)

Küresel krizin yarattı̆̆ kırılganlık atlatılmadan Euro bölgesinde bir dağılma söz konusu olursa gelişmiş ekonomiler için resesyona girme durumu oluşacaktır. Ayrıca dünya piyasalarında derin bir belirsizlik ortamı ortaya çıkacaktır. Bazı Euro bölgesi ülkeler enflasyonist baskılarla karşı karşıya kalacaklardır. Piyasalar açısından ortaya çıkan yeni para birimlerini fiyatlandırmak oldukça zor olacak ve döviz kurlarında yüksek bir volatilite söz konusu olacaktır (Alcidi, De Grauwe, Gros ve Oh, 2010:33).

Euro bölgesindeki ülkelerin ekonomik yapıları birbirine göre farklılık arz etmektedir. Bu bağlamda; krizden çıkışta cari fazla veren "merkez" ülkeler ile cari açık veren "çevre” ülkeler için aynı politika demetinin uygulanması zor görünmektedir. Ayrıca bu aşamaya gelininceye kadar ekonomik anlamda daha rahat konumda bulunan ülkeler, diğer ülkeleri kurtarmak için çeşitli fedakârlıklarda bulunmuşlardır. Dağılma olasılığının gerçekleşmemesi için bu fedakârlıkların devam etmesi olmazsa olmaz şart gibi görünmektedir. Krizden çıkışta atılan adımların sonuç vermeye başlaması ülkelerin AB'ye ve kurumlarına duyduğu güvenin artması ve ekonomik, mali politikalarda ülkeler arasında koordinasyonun artması bu olasılığın zayıflamasına neden olacak faktörlerdir. $\mathrm{Bu}$ faktörlerin gerçekleşmemesi sonucunda Euro bölgesinin dağılması olasılığından bahsedilebilir.

\section{SONUÇ}

Euro'nun ortaya çıkması; uluslararası piyasalarda eskiden beri süre gelen tek kutuplu (Dolar merkezli) yapıyı kırarak iki kutuplu bir yapı oluşmasını sağlamıştır. Bugün finansal piyasalarda da bu iki kutuplu yapı yakından takip edilmektedir. Forex piyasalarındaki gelişmeye paralel olarak dünyada üzerinde en fazla işlem yapılan enstrüman Euro/Dolar paritesidir. Parite Avrupa'daki krize rağmen başlangıç seviyesinin çok üzerinde işlem görmeye devam etmektedir. Bu durum Euro'nun gücünü korumaya devam ettiğinin ve yatırımcıların Euro’ya olan güveninin bir göstergesidir. Ayrıca dünyada Euro, ikinci en büyük rezerv para birimi olmaya devam etmektedir. Dünya ticaretinde de mübadele aracı olması bakımından önemli bir paya sahiptir. Avrupa'daki kriz devam etmesine rağmen, Euro'nun 
uluslararası bir para biriminin taşıması gereken fonksiyonların tümünü yerine getirdiğini ve uluslararası para birimi olma niteliğini devam ettirdiği görülmektedir.

Euro'nun uluslararası para birimi niteliğini devam ettirmesi geleceği açısından hayati öneme sahiptir. Euro'nun geleceğine yönelik olasılıklardan hangisinin gerçekleşeceği bununla doğrudan bağlantılıdır. Ayrıca bu olasılıklardan hangisinin geçerli olacağını belirleyecek olan diğer unsurlar; Avrupa krizinin bundan sonra alacağı şekil, Avrupa Merkez Bankası'nın ve Birliğin diğer kurumlarının krizin çözümü ile ilgili olarak atacakları adımlar, Euro Alanına dâhil olan ülkelerin takınacakları ekonomik, mali ve politik alanlardaki tavırlar olacaktır.

Euro'nun uluslararası para birimi olma niteliğini devam ettiriyor olması, Euro'nun geleceğine yönelik olarak ortaya konulan olasılıklardan var olma olasılığının gerçekleşmesini desteklemektedir. Avrupa Birliği'nde program dâhiline alınan ülkelerin borç vadelerinin uzatılması, Yunanistan ve Güney Kıbrıs konusunda uzlaşmaya varılması, dış dengesizliklerin önemli ölçüde azalması ve ulusal hükümetlerin kamu finansmanı yapılarını yenilemeleri para birliğinin devam edeceği (var olma olasılı̆̆ını) yönündeki beklentileri artıran diğer unsurlardır. Euro bölgesinde gerekli düzenlemelerin yapılmasıyla beraber ileride daha güçlü bir Euro bölgesinin ortaya çıkma olasıllı̆ 1 güçlü görünmektedir. AB'nin şu ana kadar geçirmiş olduğu süreç göz önüne alındığında hep zor zamanlardan daha da güçlenerek çıktığı göz ardı edilmemelidir. Ancak AB'de karar alma ve uygulama mekanizmasının tartışmalı ve süre alan bir şekilde işlediği düşünülürsebundan sonraki sürecin de zor geçeceği söylenebilir. Var olma olasıllı̆ın gerçekleşmesi halinde; yapısal sorunlarını çözmüş, mali, finansal ve siyasal alanda daha fazla entegre olmuş ve bundan sonra ortaya çıkabilecek krizlere karşı daha dayanıklı bir Euro bölgesinden söz edilecektir. Ancak bu kriz, bazı reformlar göz ardı edilerek atlatılırsa, o zaman ileride yeniden Euro bölgesinin dağılması durumundan söz edilebilir.

\section{KAYNAKÇA}

Ahearn, R.J.Jackson, J.K., Mix D.E.ve Nelson, R.M. (2012) "The Future Of The Eurozone and U.S. Interests", Congressional Research Service, CRS Report For Congress.

Alcidi, C., De Grauwe, P., Gros, D. ve Oh Y. (2010) “The Future Of The Eurozone and Gold”, Centre For European Policy Studies (CEPS), Brussels.

Arısan, N. (1997) “40 Soruda Ekonomik ve Parasal Birlik” İstanbul: İKV Yayınları, No:144.

Bagus, P.(2010) “The Tragedy Of The Euro”Alabama: Ludwig Von Mises Institute,.

BIS Report(2013) "Foreign Exchange Turnover In April 2013: Preliminary Global Results” Triennial Central Bank Survey, Monetary and Economic Department, September

Birinci, Y. (2001) “Euro'nun Uluslararası Finansal Piyasalar ve Türkiye Ekonomisi Üzerindeki Etkileri” İstanbul: Alfa Yayınları: 959. Dizisi No: 78. 1.Baskı.

Convergence Report (1998) European Monetary Institute, March 1998, Frankfurt. 
Coşkun, E. (2001)“Bütünleşme Sürecinde Avrupa Birliği ve Türkiye” İstanbul: Cem Yayın Evi, 1. Basim.

Curry, A. ve Lynn, M.(2012) “The Future Of The Eurozone" The Futures Company, Futures Perspectives.

De Grauwe, P. (2010) "The Financial Crisis And The Future Of The Eurozone" Bruges European Economic Policy Briefings, Beep No: 21.

ECB Montly Bullet In, August 1999.

ECB Statistical Data Ware House (Http://Sdw.Ecb.Europa.Eu/Browse.Do?Node=2018794)

ECB Statistics Pocket Book, July 2013.

IMF Annual Report 1999.

IMF Annual Report 2012.

Kar, M. (2003) “Avrupa Birliği Ve Ortak Para Politikası” (Ed. Kar ve Arıkan Avrupa Birliği Ortak Politikalar ve Türkiye), İstanbul: Beta Yayınları, İşletme Ekonomisi Dizisi 124, Yayın No: 1406, S:177-216.

Karluk, R. ve Tonus, Ö. (1998)“Avrupa Para Birliği, Euro ve Geleceği”, Anadolu Üniversitesi İ.İ.B.F Dergisi, AÜ Yayınları No:1068, İ.İ.B.F Yayınları No:146,14(1-2):261-292.

Oktar. S. ve Yavuz. S. (2000) "Euro ve Türkiye” İstanbul: Bilim Teknik Yayınevi.

Olcay, A.C.(2006) "Euro'nun Uluslararası Rolü: Amerikan Doları İle Bir Karşılaştırma” Ankara Avrupa Çalışmaları Dergisi 5(2): 131-166.

Rodrigues, M. J. (2012) "Mapping Future Scenarios For The Eurozone” International Policy Analysis, Friedrich Ebert Stiftung, Berlin.

Savaş. V. (1999)“Çağımızın Deneyi Euro” İstanbul: Siyasal Kitapevi.

Sinn, W.H.(2010) "Rescuing Europe” CES Ifo Forum Vol: 11 August.

Standard Euro Barometer 59, (2003) "Public Opinion In The European Union” European Opinion Research Group EEIG

Stark, J.(2000) "The Role Of The Euro In The World Past Developments And Future Perspectives" Bundesbank/BIS Conference On "Recent Developments In Financial Systems And The Challenges For Economic Policy” Frankfurt, 28-29 September.

Usak Raporları, (2011) “Krizdeki Birlik Euro Bölgesinin Borç Sarmalı ve AB’nin Geleceği” Rapor No:11-01

Üstünkaya, H. (2001)“Euro ve Sözleşmelere Etkisi” Ankara: Türkiye Cumhuriyet Merkez Bankası. 
World Trade Report (2013) "Factors Shaping The Future of World Trade" World Trade Organizations.

WTO Economic Research and Statistics Division (2012) "Use Of Currencies In International Trade: Any Changes In The Picture?” Staff Working Paper ERSD-2012-10. 